\title{
PENEGAKAN HUKUM AKIBAT KELALAIAN APOTEKER DALAM MENJALANKAN \\ PEKERJAAN KEFARMASIAN DI PUSKESMAS KABUPATEN BANYUMAS \\ BAEDI MULYANTO \\ mulyantobaedi@gmail.com
}

\begin{abstract}
The existence of the National Health Insurance Program organized by Healthcare and Social Security Agency (Badan Penyelenggara J aminan Sosial Kesehatan or BPJ S Kesehatan) causing increased number of visits to health centers. However, the increase patients were not followed by the increase of health human resources, especially Pharmacists. Being limited number of pharmacists who became one of the factors of negligence of pharmacist task in community healt centre.

This research aimed to analyze the implementation of Pharmaceutical care at the health center. This research also aims to analyze law enforcement due to the negligence of pharmacist task at the health center. This research methode is a qualitative by the sociological juridical approach. Collecting data through observation and interviews to 10 Pharmacists who work in health centers and the head of health centers, also the head of Indonesian P harmacist Association (IAI) in Banyumas region

The pharmaceutical care in health centers are still not in accordance with the laws and regulations that apply where the phramacist task in the health centre is still done by a non-pharmacist staff and drug information to patient also incomplete in providing drug services, it is becoming one of the factors the occurrence of negligence.

Law enforcement due to the negligence of the pharmacist in performing pharmacist task at the health center willbe solved by take out-of-court action with promote the rights of the patient or the victim, in which patients who experience the error due to the negligence of the pharmacist then directly solved by replacing drug medications error and in case undesirable of side effects from the use of drugs is carried out free medical treatment in accordance with the provisions.

In increasing the phramaceutical care at the health center should be no additional health human resources, especially pharmacists or pharmacy technical staff while minimizing an increase in visits of patients will require an active role of other health professionals to optimize preventive health efforts in the awareness level of health awareness in the community. Staff pharmacist in health center should always increase the knowledge, skills and behavior in order to maintain and improve their competence through education and training.
\end{abstract}

Key words : Pharmacist, Negligence, Law Enforcement

\section{Abstrak}

Keberadaan Program Jaminan Kesehatan Nasional, sebagai penyelenggaranya adalah Badan Penyelenggara Jaminan Sosial (BPJS), kunjungan pasien di Puskesmas meningkat, peningkatan jumlah kunjungan tidak diiringi dengan kenaikan sumber daya manusia kesehatan terutama Apoteker. Jumlah tenaga kesehatan Apoteker yang terbatas menjadi faktor terjadinya kelalaian dalam menjalankan pekerjaan kefarmasian di Puskesmas..

Penelitian ini bertujuan untuk menganalisa pelaksanaan pelayanan Kefarmasian di Puskesmas. Penelitian ini juga bertujuan untuk menganalisa penegakan hukum akibat terjadinya kelalaian apoteker dalam menjalankan pekerjaan kefarmasian di Puskesmas. Penelitian ini merupakan penelitian kualitatif dengan pendekatan yuridis sosiologis. Pengambilan data dengan observasi dan wawancara kepada sepuluh apoteker yang bekerja di Puskesmas dan Kepala Puskesmas serta informan ketua IAI cabang Banyumas.

Pelaksanaan pelayanan kefarmasian di puskesmas dimana pelayanan kefarmasian yang ada di Puskesmas masih belum sesuai dengan peraturan perundangundangan yang berlaku. Pekerjaan kefarmasian di puskesmas masih dikerjakan oleh tenaga non farmasi dan informasi obat yang diberikan pasien juga belum lengkap diberikan dalam memberikan pelayanan obat. Hal ini menjadi faktor terjadinya kelalaian. 
417 | J urnal Idea Hukum

Vol. 2 No. 2 Oktober 2016

Magister Hukum Fakultas Hukum Universitas J enderal Soedirman

Penegakan hukum akibat terjadinya kelalaian apoteker dalam menjalankan pekerjaan kefarmasian di Puskesmas diselesaikan dengan jalur di luar pengadilan dengan mengedepankan hak-hak dari pasien atau korban, dimana pasien yang mengalami kesalahan akibat kelalaian apoteker maka langsung diselesaikan dengan mengganti obat yang salah dan apabila terjadi efek samping yang tidak diinginkan dari penggunaan obat maka dilakukan pengobatan gratis sesuai dengan ketentuan.

Dalam meningkatkan pelayanan pekerjaan kefarmasian di Puskesmas hendaknya ada penambahan sumber daya manusia kesehatan terutama apoteker ataupun tenaga teknis kefarmasian sedangkan untuk meminimalisir adanya peningkatan kunjungan pasien maka diperlukan peran aktif tenaga kesehatan lain untuk mengoptimalkan upaya kesehatan preventif dalam menyadarkan tingkat kesadaran kesehatan di masyarakat. Tenaga kefarmasian di Puskesmas harus selalu meningkatkan pengetahuan, keterampilan dan perilaku dalam rangka menjaga dan meningkatkan kompetensinya melalui pendidikan dan pelatihan.

Kata Kunci : Apoteker, Kelalaian, Penegakan Hukum

\section{A. Pendahuluan}

Pelayanan kesehatan
merupakan faktor penting dalam
meningkatkan derajat kesehatan
dan kesejahteraan setiap warga
negara. Setiap warga negara
mempunyai hak dalam pelayanan
kesehatan sesuai yang tertuang
dalam Pasal 28 Hayat (1) Undang-
Undang Dasar 1945 Amandemen
kedua dinyatakan bahwa : Setiap
orang berhak hidup sejahtera lahir
dan batin, bertempat tinggal, dan
mendapat lingkungan hidup yang
baik dan sehat serta berhak
memperoleh pelayanan kesehatan.
Kesehatan sebagai hak asasi
manusia maka harus diwujudkan
dalam berbagai pelayanan
kesehatan melalui
terpadu dan berkesinambungan,
dilakukan oleh Pemerintah Pusat,
Pemerintah

adil, aman, berkualitas dan terjangkau. ${ }^{1}$ Dalam memenuhi kebutuhan akan pelayanan kesehatan, maka tersedia institusiinstitusi Rumah Sakit, Puskemas atau sarana kesehatan yang lain baik yang disediakan oleh pemerintah maupun oleh instansi swasta.

Puskesmas merupakan sarana pelayanan kesehatan strata pertama yang bertanggung jawab dalam menyelenggarakan upaya kesehatan perorangan danupaya kesehatan masyarakat di wilayah kerjanya harus ditunjang oleh tenaga kesehatan yang profesional dalam melaksanakan pelayanan kesehatan diantaranya dokter, Apoteker, Perawat dan tenaga kesehatan lainya ${ }^{2}$. Meningkatkan pelayanan kesehatan di masyarakat,

UU Nomor 36 tahun 2014 Tentang Tenaga Kesehatan, hal. 1

2 KEPMENKES No. 857 tahun 2009 Tentang Pedoman Penilaian Kinerja Sumber Daya Manusia Kesehatan di Puskesmas, hal.1. 
diperlukan adanya kerjasama

antara sumber daya manusia kesehatan, karena pelayanan kesehatan tidak menjadi monopoli salah satu tenaga kesehatan saja, tenaga kesehatan lain yang turut berperan penting dalam mewujudkan derajat kesehatan yang setinggi-tingginya adalah profesi Apoteker dalam menjalankan pelayanan kefarmasian. ${ }^{3}$ Apoteker adalah sarjana farmasi yang telah lulus sebagai Apoteker dan telah mengucapkan sumpah jabatan Apoteker. ${ }^{4}$ Profesi Apoteker harus memiliki karakter sebagaimana ciri profesi-profesi lain: (1) menjalankan pekerjaan yang memerlukan dasar dari pendidikan tinggi, (2) bekerja berdasarkan perkembangan standar sesuai dengan kemajuan ilmu pengetahuan, (3) pekerjaan yang dilakukakan semata-mata untuk kepentingan masyarakat atau kemanusiaan, (4) sadar akan kode etik profesi dan kewenagan peradilanya dalam menjaga kualitas pekerjaan,dan (5) menjalin hubungan baik dengan asosiasi/organisasi profesi yang berwenang menegakan norma disiplin di lingkungan intern anggotanya. $^{5}$

3 Bambang Poernomo, Hukum Kesehatan Pertumbuhan Hukum Eksepsional di Bidang Kesehatan. Aditya Media, Yogyakarta, 1977, hal 239.

4 Peraturan Pemerintah Nomor 51 tahun 2009 Tentang Pekerjaan Kefarmasian, hal 2.

Bambang Poernomo, loc, cit.,
Pelayanan kefarmasian di Puskesmas meliputi dua kegiatan, antara lain kegiatan yang bersifat manajerial berupa pengelolaan obat dan bahan medis habis pakai dan kegiatan pelayanan farmasi klinik. kegaitan tersebut harusdidukungoleh sumber daya manusia yang kompetenen. Penyelenggaraan pelayanan kefarmasian di puskesmas minimal harus dilaksanakan oleh 1 (satu) orang tenaga Apoteker sebagai penanggung jawab, yang dapat dibantu oleh Tenaga Teknis Kefarmsian. Rasio untuk menentukan jumlah Apoteker di Puskesmas adalah 1 (satu) Apoteker untuk 50 (lima puluh) pasien perhari. ${ }^{6}$ Pelayanan farmasi klinik merupakan pelayanan langsung yang berhubungan dengan pasien, dimana apoteker menerima resep dari pasien yang ditulis oleh dokter, terdapat dua kemungkinan obat yang harus diberikan oleh apoteker, yaitu berupa obat jadi ataupun obat racikan. Pekerjaaan apoteker sebelum memasukan obat jadi kedalam kemasan, maka apoteker terlebih dahulu mencocokan apakah obat yang akan diberikan tersebut sudah sesuai dengan yang ditulis dalam resep, bagaimana dengan kesesuaian jenis dan sifat

PERMENKES Nomor 30 Tahun 2014 Tentang Standar Pelayanan Kefarmasian Di Puskesmas, hal 8-19 
419 | J urnal Idea Hukum

Vol. 2 No. 2 Oktober 2016

Magister Hukum Fakultas Hukum Universitas J enderal Soedirman

obat, serta layakkah obat tersebut dikonsumsi oleh pasien, kemudian apoteker harus juga memperhatikan batas kadaluarsa terhadap obat tersebut sebelum diberikan kepada pasien, apoteker juga berkewajiban memberikan informasi mengenai cara penggunaan obat yang benar. Mengenai obat racikan sendiri, maka obatnya akan diracik terlebih dahulu oleh apoteker sesuai dengan permintaan dalam resep sebelum diberikan kepada pasien ${ }^{7}$.

Undang-Undang

Kesehatan Nomor 36 tahun 2009, pada Pasal 58 ayat (1) disebutkan bahwa setiap orang berhak menuntut ganti rugi terhadap seseorang, tenaga kesehatan, dan/ atau penyelenggara kesehatan yang menimbulkan kerugian akibat kesalahan atau kelalaian dalam pelayanan kesehatan yang diterimanya. Tuntutan ganti rugi terhadap tenaga kesehatan harus direalisasikan melalui penegakan hukum. Hukum berfungsi sebagai perlindungan kepentingan manusia. Agar kepentingan manusia terlindungi ${ }^{8}$.

Penegakan hukum menurut Satjipto Raharjo hakikatnya adalah setiap aktifitas dalam mewujudkan

7 Dewina, Apotek dan Pelayanan Obat serta Implikasi Yuridis, Jurnal Hukum vol 112 edisi September 2006, Fak Hukum UGM, Yogyakarta, hal 98.

8 Sudikno Mertokusumo, 2008, Mengenal Hukum Suatu Pengantar, Liberty, Yogyakarta, hal 160 . ide-ide yang sifatnya abstrak diwujudkan menjadi kenyataan. ${ }^{9}$ Sedangkan penegakan hukum menurut Abdul Wahid dan M. Muhibin menuliskan bahwa penegakan hukum dapat dilakukan dengan penindakan hukum menurut urutan sebagai berikut: ${ }^{10}$

1. Teguran peringatan supaya menghentikan pelanggaran dan jangan berbuat lagi (percobaan)

2. Pembenaan kewajiban tertentu (ganti kerugian, denda)

3. Penyisihan atau pengucilan (pencabutan hak-hak)

4. Pengenaan saksi badan (pidana penjara, pidana mati)

Mempertimbangkan adanya kelalaian tenaga kesehatan dalam menjalankan pelayanan kesehatan terutama profesi apoteker, hal inilah yang menjadi urgensi perlu adanya penelitian guna mengetahui penegakan hukum atas kelalaian yang dilakukan oleh profesi apoteker. Berdasarkan pemikiran tersebut diatas maka peneliti tertarik untuk mengadakan suatu penelitian dan menuangkanya dalam suatu penulisan hukum dalam bentuk tesis yang diberi judul : Penegakan Hukum Akibat Kelalaian Apoteker Dalam Menjalankan Pekerjaan Kefarmasian Di Puskesmas Kabupaten Banyumas.

\footnotetext{
Abdul Wahid, Moh Mubidin, 2009, Etika Profesi Hukum, Banyumedia Publishing, hal 154.

10 Abdul Wahid, Moh Mubidin, op. cit, hal 151.
} 
B. Perumusan Masalah

Berdasarkan latar belakang masalah tersebut, maka dapat dirumuskan permasalahan sebagai berikut :

1. Bagaimana pelayanan kefarmasian oleh apoteker di Puskesmas?

2. Bagaimana penegakan hukum akibat terjadinya kelalaian apoteker dalam pekerjaan kefarmasian di Puskesmas?

\section{Metode Penelitian}

1. Metode pendekatan : Yuridis Sosiologis

2. Spesifikasi Peneitian : Deskriptif

3. Lokasi Penelitian: Puskesmas Se-Kab.Banyumas

4. Sumber Data : Primer dan Sekunder

5. Pengumpulan Data : Purposive dan Snowball

6. Penyajian Data : Teks Naratif

\section{Pembahasan}

1. Pelaksanaan pelayanan kefarmasian oleh Apoteker di Puskesmas Kabupaten Banyumas.

Data dikategorisasikan menjadi beberapa aspek sorotan, yaitu jumlah kunjungan pasien, penanggung jawab gudang obat, penanggung jawab kamar obat, pelaksanaan pelayanan kefarmasian klinis, dan pelayanan informasi dan edukasi.
Berdasarkan hasil penelitian, diketahui bahwa ada beberapa permasalahan yang memang terjadi dan hal ini mendukung terjadinya faktor kelalaian apoteker dalam menjalankan pekerjaan kefarmasian di puskesmas. Jumlah kunjungan pasien yang tidak diimbangi dengan peningkatan jumlah sumber daya manusia (SDM) Kesehatan terutama apoteker, dimana jumlah kebutuhan apoteker di puskesmas harus dihitung berdasarkan rasio kunjungan pasien, baik rawat inap maupun rawat jalan serta memperhatikan pengembangan puskesmas. Rasio untuk menentukan jumlah apoteker di puskesmas adalah 1 (satu) apoteker untuk 50 (lima puluh) pasien perhari.

Dari aspek Penanggung Jawab Gudang Obat Puskesmas terdapat 2 (20\%) Puskesmas yang penanggung jawab gudang obatnya adalah apoteker, 2 (20\%) puskesmas yang peanggung gudang obatnya adalah tenaga teknis kefarmasian (TTK), 3 (30\%) puskesmas yang penanggung jawab gudang obatnya tenaga kesehatan lain, dan ada 3 (30\%) puskesmas yang penanggung jawab obatnya bukan dari tenaga kesehatan. 
421 | J urnal Idea Hukum

Vol. 2 No. 2 Oktober 2016

Magister Hukum Fakultas Hukum Universitas J enderal Soedirman

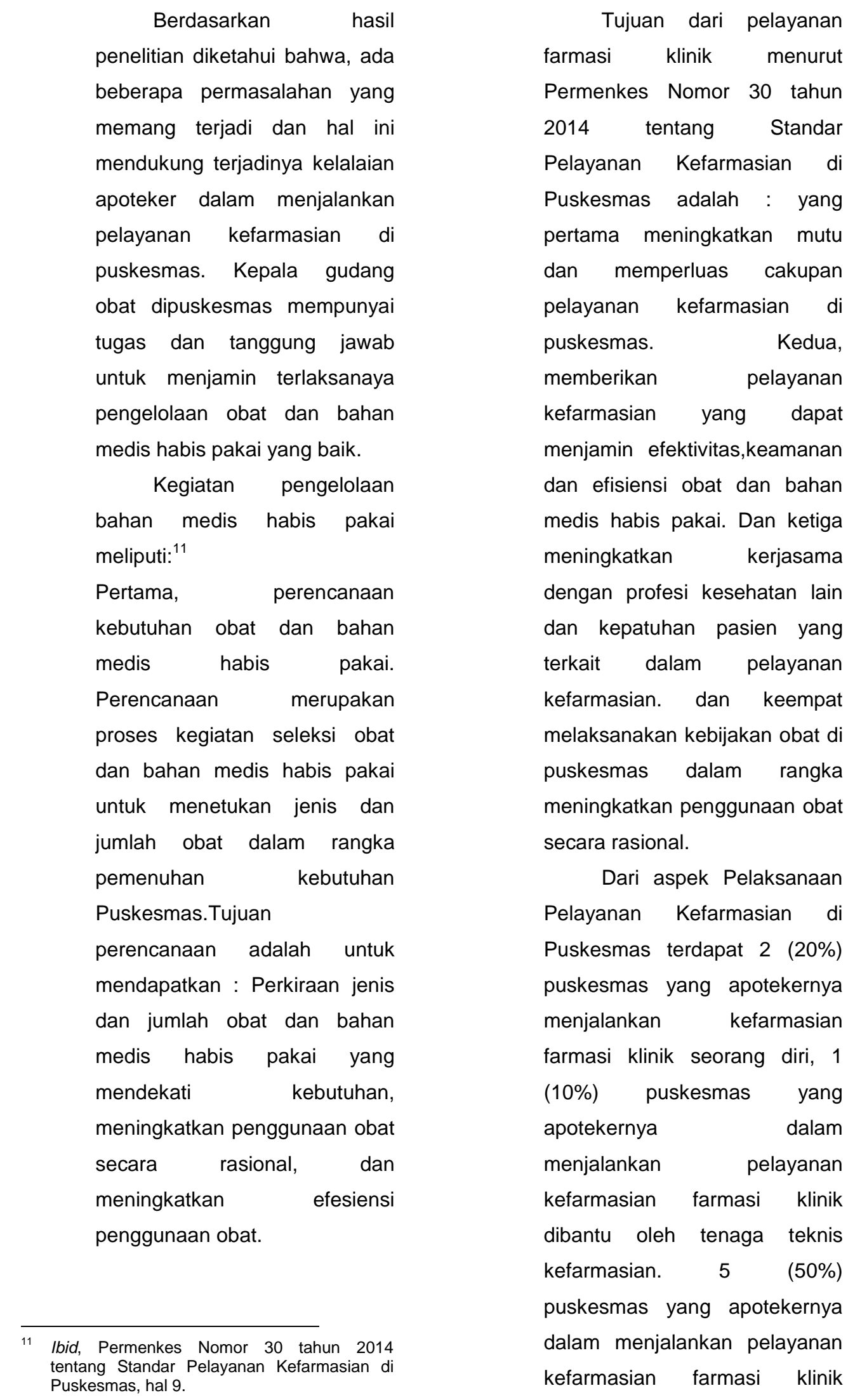


dibantu oleh tenaga kesehatan

lain, dan ada 2 (20\%)

puskesmas yang apotekernya

dalam menjalankan pelayanan

kefarmasian farmasi klinik

dibantu oleh tenaga non

kesehatan dimana ada yang

latar belakangnya adalah

administrasi dan ada juga yang

lulusan Sekolah Menengah

Pertama. Tenaga teknis

kefarmasian maupun tenaga

kesehatan lain yang

menjalankan praktek

kefarmasian secara terbatas

juga kenyataanya tidak

melakukan seccara terbatas

karena ketidakmapuan apoteker

untuk melaksanakan kontrol

pelayanan kefarmasian oleh

tenaga teknis kefarmasian dan

tenaga kesehatan lain secara

bersamaan. Tidak jarang ada

puskesmas yang memberikan

wewenang kepada tenaga yang

latar belakangya bukan dari

kesehatan bahkan ada yang

lulusan sekolah menengah

pertama melakukan pelayanan

kefarmasian dan tidak dilakukan

kontrol pengkajian resep

maupun kegiatan penyerahan

obat yang seharusnya itu

kewenangan apoteker. Tenaga

yang tidak berlatar belakang

farmasi maupun kesehatan

dalam menjalankan pekerjaan

kefarmasian tentunya sangat

disayangkan. \begin{tabular}{lrr}
\multicolumn{1}{c}{ Hal } & tersebut & juga \\
termasuk & dalam & ketentuan \\
pidana & seperti & yang \\
dicantumkan & dalam & Undang-
\end{tabular}

unadang nomor 36 tahun 2009

tentang Kesehatan. Bahwa

Setiap orang yang dengan

sengaja memproduksi atau

mengedarkan sediaan farmasi

dan/atau alat kesehatan yang

tidak memenuhi standar

dan/atau persyaratan

keamanan, khasiat dan

kemanfaatan, dan mutu

sebagaimana dimaksud dalam

Pasal 98 ayat (2) dan ayat (3)

dipidana dengan pidana penjara

paling lama 10 (sepuluh) tahun

dan denda paling banyak Rp.

1.000.000.000,00 (satu miliar

rupiah) ${ }^{12}$. Sanksi pidana untuk

orang yang memproduksi atau

mengedarkan dengan sengaja

sesuai dengan pasal (197)

dikatakan bahwa setiap orang

yang dengan sengaja

memproduksi atau

mengedarkan sediaan farmasi

dan/atau alat kesehatan yang

tidak memiliki izin edar

sebagaimana dimaksud dalam

Pasal 106 ayat (1) dipidana

dengan pidana penjara paling

lama 15 (lima belas) tahun dan

denda paling banyak Rp.

1.500.000.000,00 (satu miliar

2 Pasal 196, Undang-undang nomor 36 tahun 2009 tentang Kesehatan 
423 | J urnal Idea Hukum

Vol. 2 No. 2 Oktober 2016

Magister Hukum Fakultas Hukum Universitas J enderal Soedirman

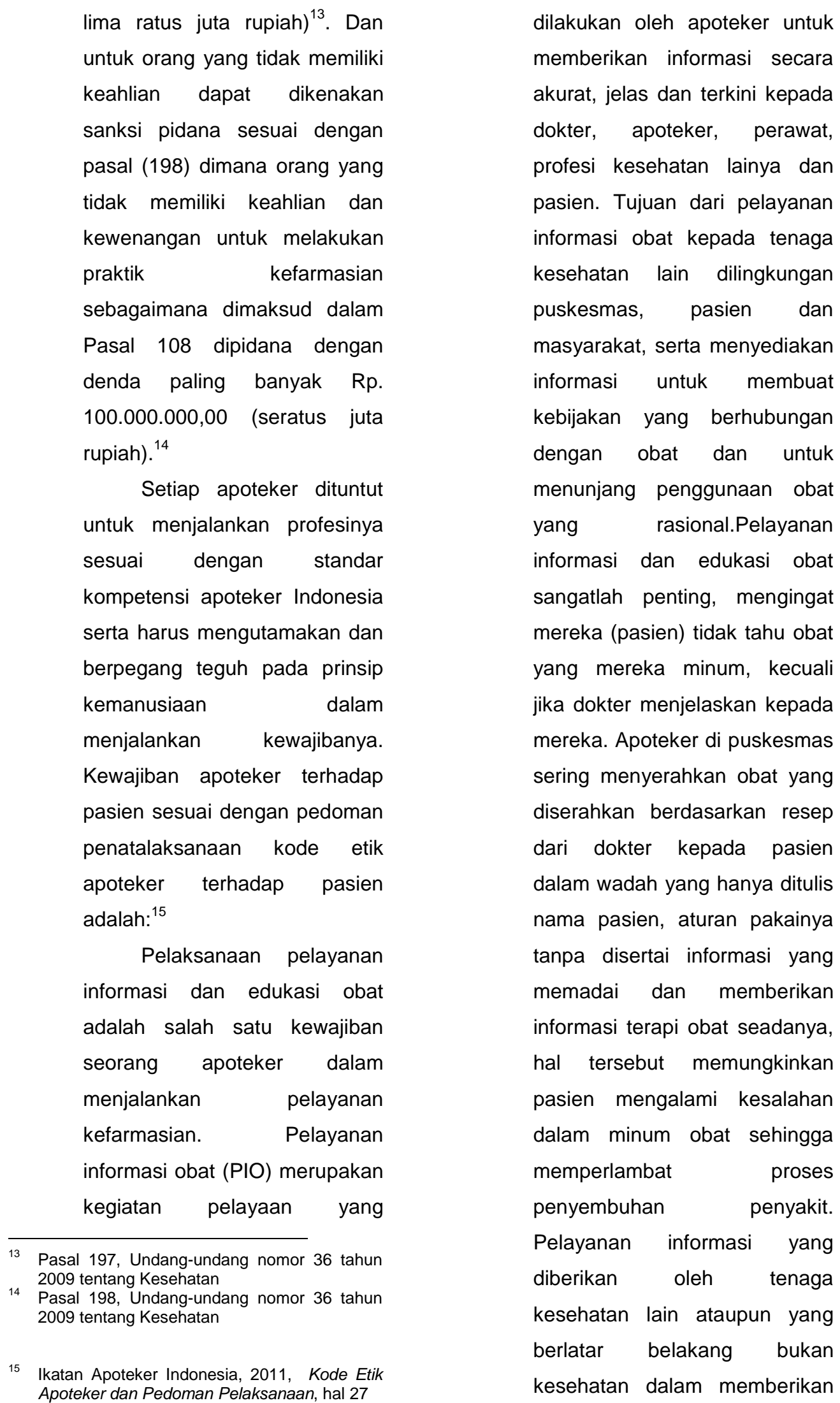


obat kepada pasien biasanya

berbagai jenis item obat yang aturan pemakaianya sama dijadikan satu dan hanya diberi satu etiket serta diberikan tanpa keterangan yang memadai sehingga ada obat yang harus diminum sampai habis dan obat yang harus memerlukan perlakuan khusus dalam minum tidak dilakukan oleh pasien. Jika keadaan ini dibiarkan terus menerus maka akan ada resistensi antibiotik karena ketidak tahuan pasien dalam minum obat dan yang ditakutkan lagi adalah adanya dosis yang berlebih sehingga ada tuntutan terhadap apoteker dalam menjalankan kefarmasian selaku yang bertanggung jawab dalam mengontrol pemberian obat oleh tenaga kesehatan lain kepada pasien.

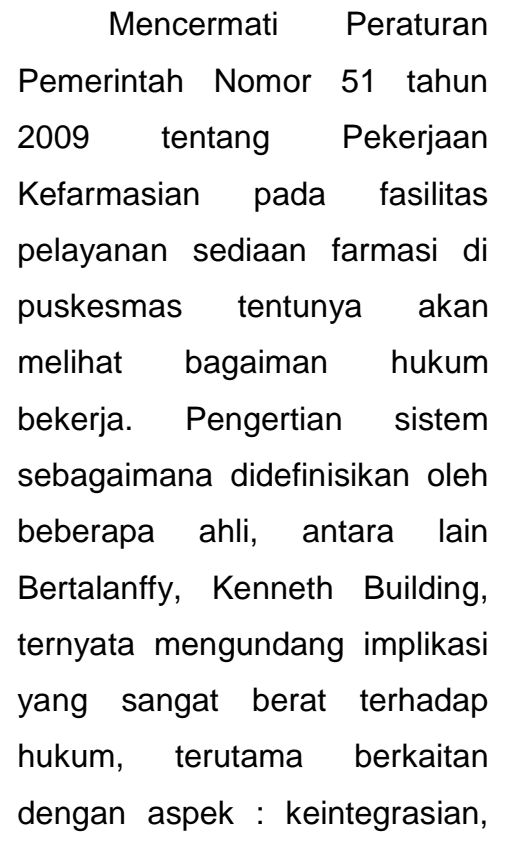

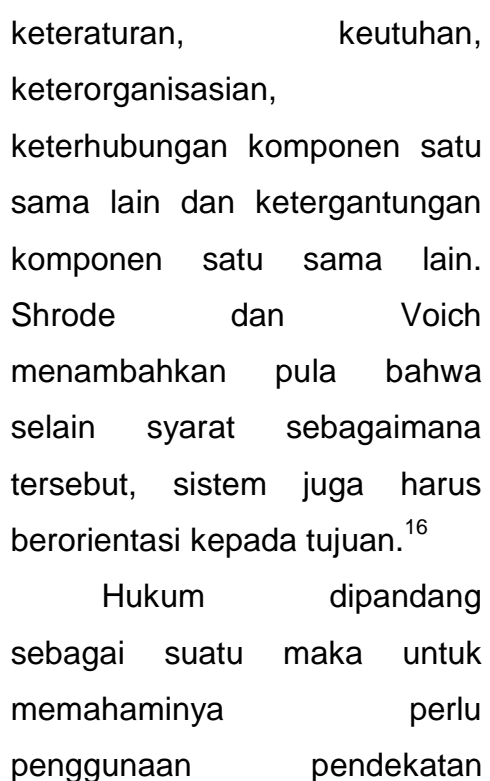
sistem. Berbagai pengertian hukum sebagai sistem hukum dikemukakan antara lain oleh Lawrence M Friedman, bahwa hukum itu merupakan gabungan antara komponen struktur, substansi dan kultur ${ }^{17}$.

komponen struktur berupa kelembagaan yang diciptakan oleh sistem hukum itu dengan berbagai macam fungsi dalam rangka mendukung bekerjanya sistem tersebut. Komponen dimungkinkan untuk dilihat bagaimana sistem hukum itu memberikan pelayanan tehadap penggarapan bahan-bahan hukum secara teratur. Komponen substantif yaitu berupa output dari sistem hukum, berupa peraturanperaturan, keputusan-keputusan

\footnotetext{
16 Esmi Warassih, 2005, P ranata Hukum Sebuah Telaah Sosiologis, Semarang, hal. 29 17 Ibid, Esmi Warassih., hal 30.
} 
425 | J urnal Idea Hukum

Vol. 2 No. 2 Oktober 2016

Magister Hukum Fakultas Hukum Universitas J enderal Soedirman

yang digunakan baik oleh pihak

yang mengatur maupun yang

diatur. Komponen kultural terdiri

dari nilai-nilai dan sikap-sikap

yang mempengaruhi bekerjanya

hukum, atau oleh Lawrence $\mathrm{M}$.

Friedman disebut sebagai kultur

hukum. Kultur hukum inilah

yang berfungsi sebagai

jembatan yang menghubungkan

antara peraturan hukum dengan

tingkah laku hukum seluruh

warga masyarakat. Komponen

kultur hukum ini hendaknya

dibedakan antara internal ilegal

culture yaitu kultur hukum para

lawyers dan judges, dan

external legal cultur yaitu kultur

hukum masyarakat luas.

2. Penegakan Hukum akibat terjadinya kelalaian Apoteker dalam menjalankan pekerjaan kefarmasian di Puskesmas.

Menurut M. Nasser

yang disebut Kelalaian medik adalah sebuah sikap atau tindakan yang dilakukan oleh dokter/dokter gigi atau tenaga kesehatan lainnya yang merugikan pasien $^{18}$. Menurut kepustakaan ada beberapa pandangan tentang kelalaian medik. Secara umum kelalaian medik dimaknai sebagai melakukan sesuatu yang tidak semestinya dilakukan atau tidak

18 M Nasser, Sengketa Medis Dalam Pelayanan Kesehatan,http://kebijakankesehatanin melakukan sesuatu yang

seharusnya dilakukan.

Berdasarkan hasil

penelitian diketahui bahwa, ada

beberapa kelalaian yang memang terjadi dan hal ini tentunya mendukung terjadinya kerugian kepada pasien dalam mendapatkan pelayanan kefarmasian di Puskesmas. Kelalaian apoteker dalam menjalankan pekerjaan kefarmasian berupa salah obat, salah pasien dan salah nama pasien diakibatkan tingkat kunjungan pasien yang begitu banyak dan masing-masing puskesmas hanya memiliki 1 (satu) apoteker yang menjalankan pekerjaan kefarmasian di puskesmas. Tuntutan pasien yang ingin segera mendapatkan obat dan kurangnya kesadaran pasien dalam mengantri untuk mendapatkan obat sebagai salah satu faktor penyebab kelalaian apoteker di puskesmas. Kelalaian berupa alergi obat dan aturan pakai obat diakibatkan apoteker tidak dapat menjalankan seccara optimal pekerjaan kefarmasian dipuskesmas, resep datang yang seharusnya dikaji oleh apoteker tidak dilaksanakan dengan baik, apoteker biasanya hanya membaca resep dan langsung menyiapkan obat 


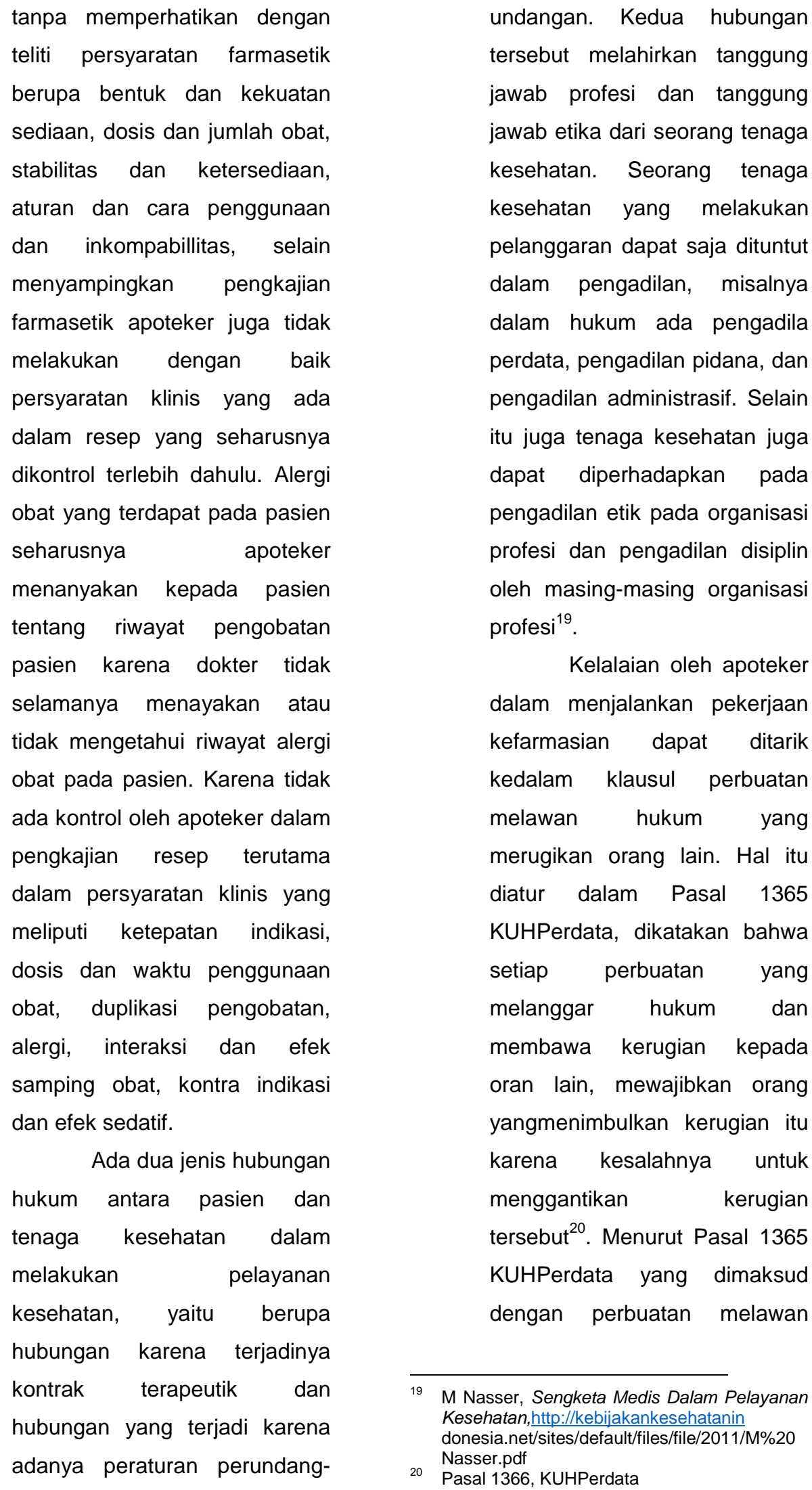


427 | J urnal Idea Hukum

Vol. 2 No. 2 Oktober 2016

Magister Hukum Fakultas Hukum Universitas J enderal Soedirman

hukum adalah perbuatan yang

melawan hukum yang dilakukan

oleh seseorang yang karena

salahnya telah menimbulkan

kerugian bagi orang lain.

Penegakan hukum atas

perbuatan melawan hukum

karena kelalaian telah diatur dalam Pasal 1367 KUHPerdata,

dikatakan bahwa tiap orang harus bertanggung jawab, bukan hanya atas kerugian yang disebabkan perbuatanperbuatan, melainkan juga atas kerugian yang disebabkan kelalaian atau kesembronoanya. $^{21}$ Tanggung jawab atas kelalaian yang dilakukan oleh apoteker dalam menjalankan pekerjaan kefarmasian dipuskesmas diatas merupakan tanggung jawab perbuatan hukum secara langsung, sedangkan untuk Kepala Puskesmas sebagai pimpinan merupakan tanggung jawab perbuatan melawan hukum seccara tidak langsung sesuai yang tercantum menurut Pasal 1367 KUHPerdata : Seseorang tidak hanya bertanggung jawab, atas kerugian yang disebabkan perbuatanya sendiri, melainkan juga atas kerugian yang disebabkan perbuatanperbuatan orang-orang yang

21 Pasal 1367, KUHPerdata menjadi tanggunganya atau disebabkan barang-barang yang berada di bawah pengawasanya. Orang tua dan wali bertanggung jawab atas kerugian yang disebabkan oleh anak-anak yang belum dewasa, yang tinggal pada mereka dan terhadap siapa mereka melakukan kekuasaan orang tua atau wali. Majikan dan orang yang mengangkat orang lain untuk mewakili urusan-urusan mereka, bertanggung jawab atas kerugian yang disebabkan oleh pelayan atau bawahan mereka dalam melakukan pekerjaan yang ditugaskan kepada orang-orang itu. Guru sekolah atau kepala tukang bertanggung jawab atas kerugian yang disebabkan oleh murid-muridnya atau tukangtukangnya selama waktu orangorang itu berada di bawah pengawasanya. Tanggung jawab yang disebutkan diatas berakhir, jika orang tua, guru sekolah, atau kepala tukang itu membuktikan bahwa mereka masing-masing tidak dapat mencegah perbuatan itu atas mana mereka seharusnya bertanggung jawab.

Penegakan hukum apoteker yang telah melakukan kelalaian tidak hanya berdimensi keperdataan. Hukum pidana menganut azas 


$\begin{array}{ll}\begin{array}{l}\text { tiada pidana tanpa kesalahan } \\ \text { atau sering disebut dengan }\end{array} & \begin{array}{l}\text { Upaya penyelesaian sengketa } \\ \text { melalui peradilan umum yang }\end{array} \\ \text { istilah geen straft } & \text { selama ini ditempuh tidak dapat } \\ \text { zonderschuld.. }{ }^{22} \text { Kelalaian } & \text { memuaskan pihak pasien, } \\ \text { merupakan salah satu jenis } & \text { karena putusan hakim dianggap } \\ \text { kesalahan, sehingga kelalaian } & \text { tidak memenuhi rasa keadilan } \\ \text { yang dilakukan apoteker bisa } & \text { pihak pasien. Hal ini disebabkan } \\ \text { juga berdimensi pada pidana, } & \text { sulitnya pasien atau Jaksa } \\ \text { seperti yang tercantum dalam } & \text { Penuntut Umum maupun Hakim } \\ \text { Pasal } 359 \text { KUHP bahwa Barang } & \text { untuk membuktikan adanya } 3 \\ \text { siapa karena kesalahanya } & \text { (tiga) kesalahan tenaga } \\ \text { (kealpaanya) menyebabkan } & \text { kesehatan. } \\ \text { orang lain mati, diancam } & \text { pembuktian } \\ \text { dengan pidana penjara paling } & \text { minimna pengetahuan mereka } \\ \text { lama lima tahun atau pidana } & \text { mengenai permasalahan- } \\ \text { kurungan paling lama satu } & \text { permasalahan tehnis sekitar } \\ \text { tahun. }{ }^{23} & \text { pelayanan medik. }\end{array}$

Penyelesaian sengketa

yang dianggap ideal bagi para

pihak adalah penyelesaian

melibatkan kedua belah pihak

yang berperkara secara

langsung sehingga

memungkinkan dialog terbuka,

dengan demikian keputusan

bersama kemungkinan besar

dapat tercapai. Disamping itu

karena pertemuan para pihak

bersifat tertutup maka akan

memberikan perasaan nyaman,

aman kepada para pihak yang

terlibat sehingga kekhawatiran

terbukanya rahasia dan nama

baik yang sangat dibutuhkan

oleh tenaga kesehatan maupun

sarana pelayanan kesehatan.

22 Bahder Johan Nasution, Hukum Kesehatan Pertanggungjawaban Dokter, Rineka Cipta, Jakarta, hal. 73

23 Pasal 359, KUHP

\section{E. Penutup}

1. Kesimpulan

Pelaksanaan pelayanan kefarmasian di Puskesmas Kabupaten Banyumas, masih belum sesuai dengan Undangundang Nomor 36 Tahun 2009 Tentang Kesehatan dan Peraturan Pemerintah Nomor 51 Tahun 2009 Tentang Pekerjaan Kefarmasian. Pekerjaan kefarmasian di puskesmas masih dikerjakan oleh tenaga non farmasi dan informasi obat yang diberikan pasien juga belum lengkap diberikan dalam memberikan pelayanan obat, hal ini menjadi salah satu faktor terjadinya kelalaian oleh apoteker dalam menjalankan pelayanan kefarmasian. 
429 | J urnal Idea Hukum

Vol. 2 No. 2 Oktober 2016

Magister Hukum Fakultas Hukum Universitas J enderal Soedirman

Penegakan hukum akibat

terjadinya kelalaian apoteker

dalam menjalankan pekerjaan

kefarmasian di Puskesmas

diselesaikan dengan jalur di luar

pengadilan,

dengan

mengedepankan hak-hak dari

pasien atau korban, dimana

pasien yang mengalami

kerugian akibat kelalaian

apoteker dalam menjalankan

pekerjaan kefarmasian,

langsung diselesaikan dengan

mengganti obat yang salah dan

apabila terjadi efek samping

yang tidak diinginkan dari

penggunaan obat maka

dilakukan pengobatan gratis

sesuai dengan ketentuan.

Apoteker yang terbukti

melakukan kelalaian dalam

menjalankan pekerjaan

kefarmasian di berikan sanksi

administratif, perdata bahkan

bisa masuk ranah pidana

2. Saran

Berdasarkan kesimpulan diatas maka dapat disarankan sebagai berikut :

a. Upaya untuk memaksimalkan pekerjaan kefarmasian di Puskesmas hendaknya dilakukan penambahan sumber daya manusia kesehatan terutama apoteker atau tenaga teknis kefarmasian. Upaya meminimalisir meningkatnya jumlah kunjungan pasien yang datang ke Puskesmas, diperlukan peran optimal dari tenaga kesehatan lain, terutama kesehatan masyarakat untuk memberikan kesadaran masyarakat tentang arti pentingya kesehatan dan selalu menjaga kesehatan.

b. Semua tenaga kefarmasian di Puskesmas harus selalu meningkatkan pengetahuan, ketrampilan dan perilaku dalam rangka menjaga dan meningkatkan

kompetensinya melalui pendidikan dan pelatihan.

\section{F. Daftar Pustaka}

Afdal, A.F. 2011. Farmasi Sosial Membuka Sisi Baru Farmasi. Penebar Swadaya, Jakarta.

Amirudin dan Z. Asikin. 2004. Pengantar Penelitian Hukum. PT. Rajawali Pers.

Budianto, Agus. 2010. Aspek Jasa Pelayanan Kesehatan Dalam Perspektif Perlindungan Pasien. Karya Putra Darwati, Bandung.

Bugin,Burhan. 2003. Analisa Data Penelitian Kualitatif, Pemahaman Filosofis dan Metodoligis Kearah Penguasaan Modal Aplikasi. PT. Raja Grafindo Persada, Jakarta.

Fajar, Mukti dan A.Yulianto. 2010. Dualisme Penelitian Hukum, Normatif \& Empiris. Pustaka Pelajar, Yogyakarta.

Fuadi,Munir. 2013. Perbuatan Melawan Hukum Pendekatan Kontemporer. Citra, Aditya Bakti, Bandung.

Jayanti, N. 2009. Penyelesaian Hukum dalam Malapraktik 
Kedokteran. Pustaka Yustisia, Yogyakarta.

Mertokusumo,Sudikno. 2008. MengenalHukumS uatuPenga ntar. Liberty, Yogyakarta.

Nasution, BJ. 2015. Hukum Kesehatan

Pertanggungjawaban Dokter. Rineka Cipta, Jakarta.

Poernomo,B. 1977.Hukum Kesehatan Pertumbuhan Hukum Eksepsional di Bidang Kesehatan. Aditya Media, Yogyakarta.

Rahardjo, S. 1980. Hukum dan Masyarakat. Angkasa, Bandung.

Machmud, S. 2008. Penegakan Hukum dan Perlindungan Hukum bagi Dokter yang diduga Melakukan Medikal Praktek. Mandar Maju, Bandung.

Soekanto, S. 2007. Faktor-faktor yang Mempengaruhi Penegakan Hukum. PT. Raja Grafindo, Jakarta.

Sudarto, 1990. Hukum Pidana I. Yayasan Sudarto, Semarang.

Susanto, IS. 2002. Pembinaan Lembaga dan Pranata Hukum. Bahan Kuliah Mahasiswa Program $\mathrm{MIH}$ UNDIP Semarang 2002 dan Program MIH UNSOED Purwokerton 2003.

Wahid, A dan M. Mubidin. 2009. Etika Profesi Hukum. Banyumedia Publishing.

Widjaja, Gunawan \&M. Kartini. 2003. Perikatan yang Lahir dari Undang-Undang. Raja Grafindo Persada, Jakarta.

\section{Sumber Lain:}

Indonesia, Undang-Undang Nomor 36 tahun 2009 tentang Kesehatan.

Indonesia, Peraturan Pemerintah Nomor 51 tentang Pekerjaan Kefarmasian.

Indonesia, Permenkes RINo 30 tahun 2014 tentang standar pelayanan kefarmasian di puskesmas.

Indonesia, Keputusan Menteri Kesehatan No 857 tahun 2009 tentang Pedoman Penilaian Kinerja Sumber Daya Manusia Kesehatan di Puskesmas.

Indonesia, Keputusan Menteri Kesehatan No 128 tahun 2004 tentang Kebijakan Dasar Puskesmas.

Ikatan Apoteker Indonesia, Kode Etik Apoteker dan Pedoman Pelaksanaan.

Tim Penyusun Kamus Pusat Pembinaan \& Pengembangan Bahasa. Kamus Besar Bahasa Indonesia, Balai Pustaka, Jakarta.

Dewina, Apotek dan Pelayanan Obat serta Implikasi Yuridis, Jurnal Hukum vol 112 edisi September 2006, Fak Hukum UGM, Yogyakarta.

Naser, M. Sengketa Medis Dalam Pelayanan Kesehatan, http://kebijakan kesehatanindonesia.net/sites/d efault/files/file/2011/M\%20Nas ser.pdf, diakses pada 10 April 2016.

Daerah.Sindonews.com/read/9503 44/kunjungan-ke-puskesmasnaik-drastis-1421208128. di akses pada 9 Oktober 2015. 